medRxiv preprint doi: https://doi.org/10.1101/2021.07.06.21260058; this version posted July 7, 2021. The copyright holder for this preprint

(which was not certified by peer review) is the author/funder, who has granted medRxiv a license to display the preprint in perpetuity.

All rights reserved. No reuse allowed without permission.

\title{
Examining Medical Student Volunteering During The COVID-19 Pandemic As A Prosocial Behavior During An Emergency
}

\author{
Matthew H V Byrne MBBS MRes ${ }^{1}$, James Ashcroft MB ChB MSc MRes MRCS ${ }^{2}$, Jonathan \\ $\mathrm{C}$ M Wan MB PhD ${ }^{3}$, Laith Alexander MB PhD ${ }^{3}$, Anna Harvey ${ }^{4}$, Nicholas Schindler MBChB \\ MRCPCH MSt ${ }^{5,6}$, Megan E L Brown MBBS ${ }^{7}$, Cecilia Brassett MB MChir MA MChir \\ $\mathrm{FRCS}^{8}$ \\ ${ }^{1}$ Nuffield Department of Surgical Sciences, University of Oxford, UK \\ ${ }^{2}$ University of Cambridge, Department of Surgery. Cambridge University Hospitals Trust, \\ UK \\ ${ }^{3}$ Guy's and St Thomas' Hospital London, UK \\ ${ }^{4}$ King's College London, UK \\ ${ }^{5}$ Norfolk and Norwich University Hospitals Foundation Trust, Paediatric Department, UK \\ ${ }^{6}$ University of Cambridge, Institute of Continuing Education, UK \\ ${ }^{7}$ Hull York Medical School, Health Professions Education Unit, UK \\ ${ }^{8}$ University of Cambridge, Department of Physiology, Development and Neuroscience, UK
}

\section{Corresponding author}

Name: Matthew Byrne

Email address: mhvbyrne@ doctors.org.uk

Full Institution address: Oxford University Hospitals Trust, Oxford UK

Institution post code: OX3 7LE

Twitter: @mhvbyrne

Alternative contact:

Name: James Ashcroft

Email address: james.ashcroft@ addenbrookes.nhs.uk

Full Institution address: Addenbrooke's Hospital, Hills Rd, Cambridge, UK

Institution post code: CB2 0QQ

\section{Author descriptions}

Dr Matthew H V Byrne is an Academic Clinical Fellow in Urology at Oxford University Hospitals Trust, UK. Dr James Ashcroft is an Academic Clinical Fellow in General Surgery at Cambridge University Hospitals Trust, UK. Dr Laith Alexander is an Academic Foundation Doctor at Guy's and St Thomas' Hospital London, Dr Jonathan Wan is an Academic Foundation Doctor at Guy's and St Thomas' Hospital London, Ms Anna Harvey is a medical student at King's College London, UK. Dr Nicholas Schindler is a tutor at the Institute of Continuing Education at the University of Cambridge and a senior pediatric registrar at Norfolk and Norwich University Hospitals Foundation Trust, UK. Dr Cecilia Brassett is a Fellow, Joint Director of Studies in Medical Sciences, College Lecturer, and Deputy Senior Tutor in Medicine at Magdalene College, University of Cambridge, and the University Clinical Anatomist, University of Cambridge.

\section{Sources of support: Nil}

Conflicts of interests: None financial or otherwise

Authorship: MHVB, JA, JW, LA were responsible for conceptualization. All authors were responsible for writing the first draft. MHVB, JA, JW, LA were responsible for data 
medRxiv preprint doi: https://doi.org/10.1101/2021.07.06.21260058; this version posted July 7, 2021. The copyright holder for this preprint

(which was not certified by peer review) is the author/funder, who has granted medRxiv a license to display the preprint in perpetuity.

All rights reserved. No reuse allowed without permission.

collection. JW was responsible for quantitative data analysis, MHVB and LA were responsible for qualitative analysis. MHVB, JA, JW, NS, CB were responsible for interpretation of data. All authors were responsible for revisions. $\mathrm{CB}$ was responsible for supervision.

Data availability: The data that support the findings of this study are available from the corresponding author upon reasonable request.

Study type: Cross sectional survey

Running Title: Medical student prosocial behavior during COVID-19

Key words (3-5 words): medical education; volunteering; preparedness; COVID-19; service learning

Number of figures: $2+3$ supplementary

Number of tables: $3+2$ supplementary

Word count: 3969 
medRxiv preprint doi: https://doi.org/10.1101/2021.07.06.21260058; this version posted July 7, 2021. The copyright holder for this preprint

\section{ABSTRACT}

2 Introduction: COVID-19 has caused major disruptions to healthcare, with voluntary

3 opportunities offered to medical students to provide clinical support. We used the conceptual

4 framework of prosocial behavior during an emergency - behaviors whose primary focus is

5 benefiting others - to examine volunteering during COVID-19.

6 Methods: We conducted an in-depth, mixed-methods cross-sectional survey, from $2^{\text {nd }}$ May to

$7 \quad 15^{\text {th }}$ June 2020, of medical students studying at UK medical schools. Data analysis was

8 informed by Latane and Darley's theory of prosocial behavior during an emergency and

9 aimed to understand students' decision-making processes.

10 Results: A total of 1145 medical students from 36 medical schools completed the survey.

11 While $947(82.7 \%)$ of students were willing to volunteer, only 391 (34.3\%) had volunteered.

12 The majority (92.7\%) of students understood that they may be asked to volunteer; however,

13 we found that deciding one's responsibility to volunteer was mitigated by a complex

14 interaction between the interests of others and self-interest. Further, concerns revolving

15 around professional role boundaries influenced students' decisions over whether they had the

16 required skills and knowledge to volunteer. Deciding to volunteer depended not only on

17 possession of necessary skills, but also seniority and identification with the nature of

18 volunteering roles offered.

19 Conclusions: We propose two additional domains to Latane and Darley's theory of prosocial

20 behavior during an emergency that students consider before making their final decision to

21 volunteer. These are 'logistics' - whether it is logistically feasible to volunteer - and 'safety'

22 - whether it is safe to volunteer. This study highlights a number of modifiable barriers to

23 prosocial behavior that medical students encounter and provides suggestions regarding how

24 Latane and Darley's theory of prosocial behavior can be operationalized within educational 
medRxiv preprint doi: https://doi.org/10.1101/2021.07.06.21260058; this version posted July 7, 2021. The copyright holder for this preprint (which was not certified by peer review) is the author/funder, who has granted medRxiv a license to display the preprint in perpetuity. All rights reserved. No reuse allowed without permission.

25 strategies to address these barriers. Optimizing the process of volunteering can aid healthcare

26 provision and may facilitate a safer volunteering process for all. 
medRxiv preprint doi: https://doi.org/10.1101/2021.07.06.21260058; this version posted July 7, 2021. The copyright holder for this preprint

\section{INTRODUCTION}

28 On $24^{\text {th }}$ March 2020, the UK Secretary of State for Health and Social Care announced plans

29 for medical students to assist in the COVID-19 pandemic ${ }^{1}$. In response to this, medical

30 schools accelerated the graduation of over 5000 final year medical students to act as interim

31 postgraduate year one doctors ${ }^{2}$, and volunteering opportunities were created for non-final

32 year students ${ }^{3}$. As clinical placements were cancelled and medical school examinations

33 postponed or replaced, there was the potential for many students to volunteer ${ }^{4,5}$.

35 Volunteering is a form of prosocial behavior - behavior which provides help to others where

36 a direct personal benefit is not a necessity but self-interest is considered ${ }^{6,7}$. As such it can

37 have positive benefits for both doctors and patients ${ }^{7}$. Prosocial behavior is an important

38 professional value in medicine ${ }^{8,9}$. Indeed, the Situational Judgement Test that final year

39 medical students in the UK must pass prior to graduation examines prosocial decision making

$40 \quad{ }^{10}$. McCrea and Murdoch-Eaton highlighted that while medical students recognize the role of

41 prosocial behavior for doctors, they often possess limited awareness of the role of prosocial

42 behavior within their current role as students ${ }^{11}$. This has relevance for student volunteering

43 during COVID-19 - a form of prosocial behavior during an emergency. Latane and Darley

44 proposed that, in prosocial behavior theories, five factors influence an individual's decision

45 to help during an emergency ${ }^{12}$, which Baron et al. posited to be the same for volunteering ${ }^{6}$.

46 They are: 1. Noticing something is abnormal; 2. Interpreting the situation as an emergency; 3.

47 Deciding you are responsible; 4. Deciding whether you have the skills or knowledge to help;

48 and 5. Making a final decision on providing help ${ }^{6,12}$. It has yet to be established whether

49 Latane and Darley's theory of prosocial behavior applies to medical student volunteering

50 during COVID-19. 
medRxiv preprint doi: https://doi.org/10.1101/2021.07.06.21260058; this version posted July 7, 2021. The copyright holder for this preprint

(which was not certified by peer review) is the author/funder, who has granted medRxiv a license to display the preprint in perpetuity.

All rights reserved. No reuse allowed without permission.

52 Studies prior to the COVID-19 pandemic have reported the readiness of medical students to

53 volunteer in hypothetical disasters and infectious disease outbreaks ${ }^{13,14}$, and early studies

54 into COVID-19 indicate that the majority of students appear willing to volunteer ${ }^{15,16}$.

55 Rasmussen et al. showed that a high percentage of medical students from a single centre in

56 Denmark wanted to volunteer $(82.4 \%)^{15}$. However, other studies have shown that, whilst

57 students are willing to volunteer during COVID-19, fewer students have actually done so ${ }^{17-}$

$58 \quad{ }^{19}$. A single centre study of 137 German medical students demonstrated that $70.1 \%$ were

59 willing to volunteer, but only $25.0 \%$ of students did ${ }^{18}$. Despite this discrepancy between

60 motivation and practice, minimal literature exists on the factors motivating students to

61 volunteer during COVID-19 ${ }^{18,20,21}$. Understanding the factors that influence prosocial

62 behavior during the current pandemic is essential, as over 40,000 medical students who are

63 studying in the UK could represent a valuable asset if empowered and mobilized as

64 volunteers ${ }^{22}$.

65

66 In view of the above, we conducted an in-depth, mixed-methods survey to explore

67 volunteering among UK medical students during COVID-19, using the conceptual

68 framework of prosocial behavior described by Latane and Darley, and Baron et al. ${ }^{6,12}$.

69 Through developing an understanding of students' motivations to volunteer, we aimed to

70 identify educational strategies which support prosocial behaviors during emergencies to

71 support medical education volunteering pathways. 
medRxiv preprint doi: https://doi.org/10.1101/2021.07.06.21260058; this version posted July 7, 2021. The copyright holder for this preprint

(which was not certified by peer review) is the author/funder, who has granted medRxiv a license to display the preprint in perpetuity.

All rights reserved. No reuse allowed without permission.

\section{METHODS}

\section{Research approach}

74 This research was conducted within the paradigm of pragmatism. Pragmatism concerns itself

75 with problem solving, and often utilizes mixed-methods approaches ${ }^{23}$. In line with our

76 pragmatic orientation, we chose not to forefront considerations of epistemology and ontology

$77^{24}$, and focused on designing an effective study expeditiously within the new research

78 landscape mandated by COVID-19. As such, an online survey was selected for data

79 collection for ease of dissemination and wide reach. Questions were asked with both

80 quantitative and qualitative outputs to provide broad and rich data reflective of a wide range

81 of experiences ${ }^{25}$.

\section{Survey}

83 We conducted a cross-sectional survey from $2^{\text {nd }}$ May to $15^{\text {th }}$ June 2020 of students studying

84 at UK medical schools, following the STROBE guideline for cross-sectional studies ${ }^{26}$. The

85 survey consisted of 53 questions assessing previous clinical experience, attitudes to

86 volunteering, motivation and barriers, volunteering role, medical education, issues currently

87 faced, and safety (Appendix 1). Survey development was informed by a systematic review of

88 existing literature on volunteering during pandemics and disasters, and previously used scales

$89{ }^{27}$. Questions were then developed by MHVB and JA with expert input and consultation with

90 medical students, and final questions were reviewed by medical students to establish face

91 validity. The survey was hosted on Google Forms with no identifiable data collected, and

92 data were held on a secure server. 
medRxiv preprint doi: https://doi.org/10.1101/2021.07.06.21260058; this version posted July 7, 2021. The copyright holder for this preprint

(which was not certified by peer review) is the author/funder, who has granted medRxiv a license to display the preprint in perpetuity.

All rights reserved. No reuse allowed without permission.

\section{Student recruitment}

94 We used a convenience sampling approach to recruit medical students. Medical schools listed

95 on the UK Medical Schools Council website were invited via email to distribute the survey to

96 their students ${ }^{28}$. Messages were posted once a week to Twitter and Facebook asking medical

97 students to complete and share the survey to recruit more participants via a snowball

98 approach.

\section{Ethics}

100 Ethical approval for the study was obtained from the University of Cambridge Psychology

101 Research Ethics Committee (PRE.2020.040).

\section{Quantitative analysis}

103 We asked students to indicate their level of agreement using a 5-point Likert scale

104 (1=strongly disagree; 5=strongly agree) on items representing volunteering, role, clinical

105 skills, motivation/barriers to volunteering, issues with volunteering, and risk and safety.

106 Statistical analysis was performed by JW using R (version 4.0.1) ${ }^{29}$. Data are presented as

107 mean \pm standard deviation (SD) and as percentages in each category of the Likert scale.

108 Correction for multiple testing was performed using a Benjamini-Hochberg correction in $\mathrm{R}$

109 using the rstatix package.

111 Multiple linear regression of predictors for 'I am willing to volunteer (Likert)' was performed

112 in R using $\operatorname{lm}()$. For this model, the variables used were 'year at medical school' and survey

113 responses around beliefs for the prediction of volunteering status. Data for subgroups were

114 analysed separately and included in the multiple regression model. These groups were chosen

115 to ascertain whether attitudes differed between years at medical school and if any differences

116 existed between those who chose to volunteer and those who did not. Entries with missing 
medRxiv preprint doi: https://doi.org/10.1101/2021.07.06.21260058; this version posted July 7, 2021. The copyright holder for this preprint

117 data were excluded from the analysis using the na.omit function in R. Backward stepwise

118 model selection was performed using stepAIC() from the MASS package.

\section{Qualitative analysis}

120 Thematic analysis was used to analyse qualitative responses using the six-step approach

121 described by Braun and Clarke ${ }^{30}$. Two authors (LA and MHVB) familiarised themselves

122 with the data, and created initial inductive, descriptive codes for all data. To identify themes,

123 a semantic approach was used. Initial codes were analysed for patterns, grouped,

124 summarised, and interpreted. Themes and subthemes were checked against the initial codes

125 and the data set as a whole, and any interpretative discrepancies explored and resolved by

126 consensus. Themes and subthemes were then reviewed, discussed, and agreed by all authors.

\section{Applying Latane and Darley's theory of prosocial behavior during an emergency as a}

\section{8 theoretical lens}

129 To analyse how our data applied to Latane and Darley's theory of prosocial behavior during 130 an emergency, we used a theory-informing inductive data analysis approach ${ }^{31}$. We did not

131 impose our definition of prosocial behavior during an emergency upon participants, instead

132 allowing them to express their own views in response to questions. We first performed our

133 quantitative and qualitative analysis, later applying Latane and Darley's theory to our data as

134 a 'sensitizing concept'. Though sensitizing concepts originate from the methodology of

135 constructivist grounded theory ${ }^{32}$, they have since been applied as part of reflexive analysis in

136 a way that aligns with Varpio et al.'s 'theory informing inductive data analysis' approach ${ }^{33}$.

137 This is the way in which we utilized theory within this study.

138 Data were reviewed using this theoretical framework by MHVB and MELB, and areas of

139 concordance and conflict explored and highlighted, then discussed and agreed by all authors. 
medRxiv preprint doi: https://doi.org/10.1101/2021.07.06.21260058; this version posted July 7, 2021. The copyright holder for this preprint (which was not certified by peer review) is the author/funder, who has granted medRxiv a license to display the preprint in perpetuity.

All rights reserved. No reuse allowed without permission.

\section{Reflexivity statement}

141 The authors of this study comprise a diverse range of doctors in training, medical students,

142 medical education researchers, and consultants across multiple educational institutions. The

143 range of experiences at different stages and institutions permitted a wide scope of viewpoints

144 regarding the data, thus enriching analysis. 
medRxiv preprint doi: https://doi.org/10.1101/2021.07.06.21260058; this version posted July 7, 2021. The copyright holder for this preprint (which was not certified by peer review) is the author/funder, who has granted medRxiv a license to display the preprint in perpetuity.

All rights reserved. No reuse allowed without permission.

\section{RESULTS}

\section{Demographics}

147 A total of 1145 students from 36 medical schools were represented in this study (Figure S 3:

148 Roles students are willing to perform while volunteering grouped by year.). The median age

149 of respondents was 22 (interquartile range, IQR, 20-24), 835 (73.0\%) were women, 75

$150(6.6 \%)$ were intercalating (taking time out of medical school to complete an additional

151 degree), and $170(14.8 \%)$ were in their fifth or sixth year of medical school (Figure S 1). Of

152 these final-year students, 112 out of $170(65.9 \%)$ had already graduated.

153

\section{Quantitative analysis}

155 Results are structured within both qualitative and quantitative sections following the domains

156 of Latane and Darley's theory of prosocial behavior during an emergency.

157 Noticing something is abnormal and interpreting the situation as an emergency

158 The majority of students $(92.7 \%)$ recognized that medical students might be asked to

159 volunteer due to COVID-19. We interpret this as widespread recognition of an abnormal,

160 emergency situation.

$161 \quad$ Deciding responsibility

162 Across all year groups, 947 out of 1145 students (82.7\%) strongly agreed or agreed with the

163 statement 'I would be willing to volunteer to work', which suggests that most students felt

164 responsible for helping (Figure S 2). The reasons for this were complex, with a wide range of

165 motivating and barrier factors for volunteering (Table 1). Factors influencing the

166 responsibility to volunteer can be divided into two groups: in the interest of others and self-

167 interest. The former included altruism, moral obligation, family or social commitments, 
medRxiv preprint doi: https://doi.org/10.1101/2021.07.06.21260058; this version posted July 7, 2021. The copyright holder for this preprint

168 others' safety, societal expectations, medical school expectations, and peer pressure; the latter

169 included professional development, academic and work commitments, personal safety,

170 psychological impact, discrimination, and financial implications.

171 While most students were willing to volunteer, less than half of the students felt they should

172 be encouraged to volunteer (Figure S 2).

\section{Deciding whether you have the skills or knowledge to help}

174 Eighty percent of students felt they would have a positive impact by volunteering. We

175 assessed students' preference for specific volunteer roles, and their confidence in the skills

176 required for these roles.

177 We asked students to indicate the roles they were willing to perform as volunteers. Twenty-

178 six percent of students strongly agreed or agreed that they were willing to perform the full

179 clinical role of a doctor, whereas $857(75.3 \%)$ and $882(77.7 \%)$ were willing to undertake an

180 assistant medical role or provide indirect medical care (such as providing meals or moving

181 patients), respectively. The majority of students were willing to perform the same role on a

182 ward with patients with COVID-19 (n=943, 82.3\% strongly agreed or agreed, Figure 1).

183 Senior students were more willing to perform the full clinical role expected of a doctor but

184 were less willing to provide indirect medical care (Figure S 3).

185 We looked at student confidence in skills required for these roles using a Likert scale (Figure

186 1). Across all year groups, students were most confident in clerking new admissions

187 (mean=3.4/5, 95\% $\mathrm{CI}=3.3-3.5)$ and performing venepuncture (mean=3.4/5, 95\% $\mathrm{CI}=3.3-3.5)$.

188 Students were least confident in prescribing medication (mean=2.0/5, 95\% CI=1.9-2.0) and

189 initiating management plans for patients (mean=2.1, 95\% CI=2.0-2.1). For all skills except

190 for donning and doffing PPE, there was a significant positive correlation between the

191 respondents' year group and their confidence in performing them (Benjamini-Hochberg

192 adjusted $\mathrm{P}<0.05)$. 
medRxiv preprint doi: https://doi.org/10.1101/2021.07.06.21260058; this version posted July 7, 2021. The copyright holder for this preprint (which was not certified by peer review) is the author/funder, who has granted medRxiv a license to display the preprint in perpetuity.

All rights reserved. No reuse allowed without permission.

193 Making a final decision to provide help by volunteering

194 At the time of the study, 391 of 1145 students (34.3\%) had volunteered during the pandemic

195 (Figure S 1). This ranged from 14.6\% amongst first-year students to 54.1\% in final year (year

196 five or six). A significantly lower proportion of intercalating students were volunteering

197 compared to their clinical counterparts in the same years $(20.0 \%$ vs. $33.5 \%, \mathrm{P}=0.02$, Chi-

198 square test). The median start date of those who had begun volunteering was $16^{\text {th }}$ April 2020,

199 three weeks after the UK was placed into lockdown. Of the 391 students who were

200 volunteering in the pandemic, $77(22.2 \%)$ had taken up roles as interim postgraduate year one

201 doctors (Table S 1).

202

203 The strongest predictors of willingness to volunteer using multiple linear regression were the

204 beliefs that volunteering to work would benefit a student's medical education

205 (estimate $=0.35 \pm 0.03$, adjusted $\mathrm{P}<0.001$, Table $\mathrm{S} 2$ ) and that the student would make a

206 positive impact (estimate $=0.33 \pm 0.03$, adjusted $\mathrm{P}<0.001$ ). Students who believed there were

207 ethical issues with asking medical students to volunteer were less likely to volunteer

208 (estimate $=-0.08 \pm 0.02$, adjusted $\mathrm{P}<0.001$ ), as were those who had begun considering a career

209 outside of medicine because of the pandemic (estimate $=-0.08 \pm 0.02$, adjusted $\mathrm{P}=0.001$ ).

210 Increasing age was a significant negative predictor of willingness to volunteer, independent

211 of medical school year group, after correction for multiple testing (adjusted $\mathrm{P}=0.043$ ).

212 Additional factors which influenced making a final decision to provide help

213 Across all year groups, the median self-estimated probability of contracting COVID-19 was

$21450.0 \%(\mathrm{IQR}=20.0 \%-65.0 \%, \mathrm{n}=962)$, which was not influenced by year or volunteering.

$21543.5 \%(n=475)$ felt there was a lack of information regarding volunteering opportunities

216 available. 
medRxiv preprint doi: https://doi.org/10.1101/2021.07.06.21260058; this version posted July 7, 2021. The copyright holder for this preprint (which was not certified by peer review) is the author/funder, who has granted medRxiv a license to display the preprint in perpetuity.

All rights reserved. No reuse allowed without permission.

\section{Qualitative analysis}

218 Our qualitative analysis focused on the later stages of the decision-making process. We asked

219 students what ethical concerns they had about volunteering and the issues they anticipated

220 they would face while volunteering (Table 2). We defined five themes: Pressure to volunteer;

221 Education; Professional practice; Safety; and Logistics.

\section{Deciding responsibility}

223 Two themes were relevant to deciding responsibility: pressure to volunteer and education.

224 Students expressed feelings such as guilt, obligation and, even a sense of coercion. There

225 were concerns that opportunities may not be promoted in a neutral way and that it should be

226 students' own choice to volunteer rather than due to pressure from external organizations

227 (Table 2).

228 The theme of education was also relevant to deciding responsibility. Some students felt that

229 volunteering was an opportunity to replace disrupted teaching opportunities, whereas others

230 found there was a conflict between volunteering and studying for their medical degree, which

231 was compounded by a perceived lack of training for volunteers (Table 2).

\section{Deciding whether you have the skills or knowledge to help}

233 Regarding skills or knowledge required, we identified concerns surrounding the themes of

234 professional practice and safety. Students were concerned about their competency and

235 questioned the usefulness of inexperienced medical students, as they might constitute a

236 burden. These concerns were closely linked to safe practice - that patient care might be

237 affected due to working outside of competency, especially if there was a lack of supervision

238 or clarity regarding the professional role boundaries of new doctors. 
medRxiv preprint doi: https://doi.org/10.1101/2021.07.06.21260058; this version posted July 7, 2021. The copyright holder for this preprint

(which was not certified by peer review) is the author/funder, who has granted medRxiv a license to display the preprint in perpetuity.

All rights reserved. No reuse allowed without permission.

240 Additional factors which influenced making a final decision to provide help

241 The theme of safety also played a key role in decision making. This included considerations

242 of personal safety, the risk of contracting COVID-19 (particularly with inadequate PPE, or

243 for students with pre-existing health issues), as well as the psychological impact and stress of

244 working during a pandemic. Students were concerned about transmitting COVID-19 to

245 others, the risk posed to vulnerable family members, or disruption to pre-existing caring

246 duties.

247 Our qualitative analysis revealed a final barrier not accounted for by Latane and Darley's

248 theory: 'logistics'. These were concerns of support outside of work, and difficulties with

249 transport, accommodation, and administration.

250 
medRxiv preprint doi: https://doi.org/10.1101/2021.07.06.21260058; this version posted July 7, 2021. The copyright holder for this preprint

\section{DISCUSSION}

252 In this study, we identified that $82.7 \%$ of medical student respondents would be willing to 253 volunteer; however, only $34.5 \%$ were volunteering at the time of the survey. While other

254 studies have shown a similar association, they have not explored the reasons why this may be

255 the case in depth ${ }^{17-19}$. Studies in other fields have demonstrated an intention to behavior gap

$256{ }^{34}$, which may explain part of the discrepancy. However, such a large difference suggests the

257 presence of additional factors influencing students' decisions to volunteer. Latane and

258 Darley's theory of prosocial behavior during an emergency outlines a five-step process

259 influencing the decision-making process to help in emergency situations that we have used as

260 a conceptual framework ${ }^{126}$. But how do our findings fit with what is already known?

261

262 Although McCrea and Murdoch-Eaton suggest medical students possess little awareness of

263 the applicability of prosocial behavior to their role ${ }^{11}$, our study shows this does not appear to

264 be the case during COVID-19. The majority of students did recognize that COVID-19 was an

265 abnormal situation, that it was an emergency, and that they may be responsible. This may be

266 due, in part, to widespread media coverage, but is also likely a result of clinical placement

267 suspension, and students witnessing the vast number of healthcare staff involved in

268 responding to the pandemic. Time to reflect on a situation ${ }^{35}$, as well as the presence of others

269 providing help, has been shown to influence likelihood of a decision to help ${ }^{36}$.

270

271 The gap between an intention to volunteer and volunteering in practice could be explained by

272 the ways in which students decided their responsibility to volunteer during in the pandemic.

273 This decision was complex, and influencing factors can be conceptualized as a balance

274 between the interest of others and self-interest. Although $82.7 \%$ of students were willing to

275 volunteer, prosocial behaviors can be influenced by others ${ }^{37}$. This is shown in our cohort by 
276 a 'pressure to volunteer'. Prosocial peer norms ${ }^{38}$, and external influences (such as school and 277 parents) have been shown to motivate prosocial behavior ${ }^{37}$. Individuals are more likely to 278 volunteer with "in-groups" (those close to them) rather than "out-groups" (those distant to 279 them) ${ }^{39}$. Thus, increased social distance between helpers and those being helped reduces 280 prosocial behavior ${ }^{40}$, as does social exclusion ${ }^{41}$. For medical students, academic and clinical 281 studies were interrupted - especially for those in later years used to high levels of patient 282 contact - with many medical students returning home because of COVID-19. This may have 283 increased the perceived social distance between patients, as well as between peers, shifting 284 the balance of prosocial behavior towards self-interest.

286 Latane and Darley suggest that, after having assumed responsibility, people decide whether 287 they have appropriate skills to help during emergencies ${ }^{12}$. Similarly, we found that medical 288 students make a series of 'competency' judgements regarding volunteering, which includes 289 considerations as to how their level of ability relates to the proposed volunteering role and 290 level of supervision, and how these factors might influence patient safety. There was an 291 incremental increase in their confidence in the required skills and their willingness to perform 292 more advanced roles as the year of the student increased, such that final year students were 293 less willing to provide indirect care even though they had the skills to do so. Our data suggest 294 that this decision depends not only on the skills required, but also on the roles offered and the 295 year of the student. We posit that this is a domain which could result in a large decrease in 296 prosocial behavior during COVID-19. Our qualitative data showed that students felt 297 uncertain as to the professional role boundaries of volunteers; they perceived a lack of clarity 298 regarding voluntary roles and were worried that they might be asked to perform tasks outside 299 of their competence. Concerns surrounding roles could also reflect the variation of roles 300 across the country ${ }^{42-46}$. Clarity regarding roles and necessary skills could facilitate prosocial 
medRxiv preprint doi: https://doi.org/10.1101/2021.07.06.21260058; this version posted July 7, 2021. The copyright holder for this preprint

301 behavior amongst medical students during emergencies. Presenting students with more

302 options involving a wider range of roles could also help, as having a number of options by

303 which one could help has been shown to facilitate prosocial behavior ${ }^{47}$.

304

305 Finally, in Latane and Darley's theory, an individual weighs the above considerations and

306 makes a final decision ${ }^{12}$. We found that significantly fewer students who were intercalating

307 (taking time out of medical school to complete an additional degree) volunteered. This lends

308 weight to our observation about social distance, as intercalating students may be further

309 removed from patients, healthcare professionals, and medical schools. We also showed that

310 far more final-year students had volunteered than first-year students. This supports our

311 arguments about role and skills alignment. Students in higher years are likely to possess a

312 higher level of self-efficacy - the ability to overcome barriers to achieve a goal - which can

313 influence prosocial behavior ${ }^{6,48}$. Interestingly, in contrast to this finding, Burks and Kobus

314 found that prosocial values decrease as students' progress through training ${ }^{7}$. We posit that

315 the main reason for the difference between this study and Burks and Kobus' research is that

316 final year students had a clear interim postgraduate year one role that they could fulfil, which

317 students in other years lacked. Regarding barriers to volunteering, $43.5 \%$ of respondents felt

318 there was lack of information on volunteering opportunities available. 'Logistics' was the

319 first of two areas that had not been explained in Latane and Darley's theory of prosocial

320 behavior during an emergency. Our data would indicate that - a volunteer must decide

321 whether logistically they can volunteer. Previous literature surrounding the willingness of

322 medical students to volunteer in a disaster relied on the assumption that in a crisis there

323 would be an established framework and infrastructure for mobilizing medical students.

324 However, this was not the case in the UK during the early part of 2020. Early narrative work 
medRxiv preprint doi: https://doi.org/10.1101/2021.07.06.21260058; this version posted July 7, 2021. The copyright holder for this preprint

(which was not certified by peer review) is the author/funder, who has granted medRxiv a license to display the preprint in perpetuity.

All rights reserved. No reuse allowed without permission.

325 from the USA has centered on development of volunteering infrastructure, including the

326 establishment of voluntary task forces ${ }^{49}$, with similar initiatives occurring in the UK ${ }^{50}$.

327

328 The second key area that had not been adequately encapsulated by Latane and Darley's

329 theory concerned 'safety'. Although considerations of safety may take place within decisions

330 of responsibility, or of skills and knowledge, our data demonstrate that concerns regarding

331 safety were an integral part of volunteering decision-making. We posit that medical students

332 must also decide whether it is safe to volunteer - in the interests of themselves and others.

333 We present our conceptual framework for medical student volunteering during COVID-19 in

334 Figure 2.

335

336 Understanding the factors that influence prosocial behavior during COVID-19 can support

337 future decision-making around the infrastructure and processes that must be put in place to

338 effectively facilitate the mobilization of students during the current pandemic and in any

339 future crises. Creating a comprehensive strategy for how to manage and implement

340 volunteers is beyond the scope of this article. We have provided suggestions in Table 3 of

341 how our conceptual framework can be used in educational strategies to facilitate medical

342 student prosocial behavior during pandemics and disasters ${ }^{51}$. These could be introduced

343 using pre-existing frameworks for innovation, and could be used to develop a flexible

344 structure that is organized at a local level with national oversight, which could allow for a

345 rapid goal-orientated coordinated response ${ }^{52,53}$. Developing this infrastructure is even more

346 important in view of the 'second wave' of COVID-19 cases ${ }^{54,55}$ in Europe ${ }^{56}$, and high

347 numbers of cases in the USA ${ }^{57}$. 
medRxiv preprint doi: https://doi.org/10.1101/2021.07.06.21260058; this version posted July 7, 2021. The copyright holder for this preprint

(which was not certified by peer review) is the author/funder, who has granted medRxiv a license to display the preprint in perpetuity.

All rights reserved. No reuse allowed without permission.

\section{$348 \quad$ Limitations}

349 To expedite survey distribution, we did not perform focus groups and cognitive interviews as

350 part of our survey development, and this may have limited how participants interpretated the

351 questions ${ }^{58}$. However, medical students were involved throughout the survey development

352 process. As we were unable to identify the survey response rate, our data may not be wholly

353 representative of the whole UK cohort. We tried to mitigate this by distributing the survey

354 through multiple channels. There is selection bias, as the types of medical student who opt to

355 fill in the survey may be more willing to volunteer. Further, the transferability of our findings

356 may be limited by the higher number of women who participated. Finally, this study was

357 cross-sectional in nature, and could not determine whether students' motivation to volunteer

358 evolved as the context of the pandemic changed. Longitudinal research regarding the ways in

359 which prosocial behaviors expression changes as emergency situations develop would be of

360 benefit in future. 
medRxiv preprint doi: https://doi.org/10.1101/2021.07.06.21260058; this version posted July 7, 2021. The copyright holder for this preprint (which was not certified by peer review) is the author/funder, who has granted medRxiv a license to display the preprint in perpetuity.

All rights reserved. No reuse allowed without permission.

\section{CONCLUSIONS}

362 This study demonstrates that Latane and Darley's theory of prosocial behavior during an

363 emergency can be applied to medical student volunteering during COVID-19. This study

364 expands on existing theory through addition of the domains of safety and logistics in the

365 decision-making process. We identified a number of modifiable barriers to prosocial behavior

366 encountered by medical students during COVID-19 and provide suggestions of how our

367 conceptual framework can be used within educational strategies to address such barriers.

368 Optimizing the process of volunteering can aid workforce planning and healthcare provision,

369 and may facilitate a volunteering process that is safer for students, staff, and patients. 
medRxiv preprint doi: https://doi.org/10.1101/2021.07.06.21260058; this version posted July 7, 2021. The copyright holder for this preprint (which was not certified by peer review) is the author/funder, who has granted medRxiv a license to display the preprint in perpetuity.

All rights reserved. No reuse allowed without permission.

\section{REFERENCES}

371 1. Siddique H. Final-year medical students graduate early to fight Covid-19. The

$372 \quad$ Guardian. 2020.

373 2. Iacobucci G. Covid-19: medical schools are urged to fast-track final year students.

$374 \quad$ BMJ. 2020;368:m1064. doi:10.1136/bmj.m1064

375 3. Medical Schools Council. STATEMENT OF EXPECTATION Medical Student

$376 \quad$ Volunteers in the NHS.; 2020.

377 4. O'Byrne L, Gavin B, McNicholas F. Medical students and COVID-19: the need for 378 pandemic preparedness. J Med Ethics. 2020:medethics-2020-106353.

379 doi:10.1136/medethics-2020-106353

380 5. Arora A, Solomou G, Bandyopadhyay S, et al. Adjusting to Disrupted Assessments,

381 Placements and Teaching (ADAPT): a snapshot of the early response by UK medical

382 schools to COVID-19. medRxiv. August 2020:2020.07.29.20163907.

383 doi:10.1101/2020.07.29.20163907

384 6. Baron RA, Byrne D, Branscombe NR. Mastering Social Psychology. Boston: Pearson $385 \quad$ Education, Inc; 2007.

386 7. Burks DJ, Kobus AM. The legacy of altruism in health care: The promotion of

387 empathy, prosociality and humanism. Med Educ. 2012;46(3):317-325.

388 doi:10.1111/j.1365-2923.2011.04159.x

389 8. Arnold EL, Blank LL, Race KEH, Cipparrone N. Can professionalism be measured?

390 The development of a scale for use in the medical environment. Acad Med.

391 1998;73(10):1119-1121. doi:10.1097/00001888-199810000-00025

392 9. Leffel GM, Oakes Mueller RA, Ham SA, Karches KE, Curlin FA, Yoon JD. Project

393 on the Good Physician: Further Evidence for the Validity of a Moral Intuitionist Model

394 of Virtuous Caring. Teach Learn Med. 2018;30(3):303-316. 
medRxiv preprint doi: https://doi.org/10.1101/2021.07.06.21260058; this version posted July 7, 2021. The copyright holder for this preprint (which was not certified by peer review) is the author/funder, who has granted medRxiv a license to display the preprint in perpetuity.

All rights reserved. No reuse allowed without permission.

395

396

397

398

399

400

401

402

403

404

405

406

407

408

409

410

411

412

413

414

415

416

417

418

419

doi:10.1080/10401334.2017.1414608

10. Patterson F, Zibarras L, Ashworth V. Situational judgement tests in medical education and training: Research, theory and practice: AMEE Guide No. 100. Med Teach. 2016;38(1):3-17. doi:10.3109/0142159X.2015.1072619

11. McCrea ML, Murdoch-Eaton D. How do undergraduate medical students perceive social accountability? Med Teach. 2014;36(10):867-875.

doi:10.3109/0142159X.2014.916784

12. Latané B, Darley JM. The Unresponsive Bystander: Why Doesn't He Help? New York: Appleton-Century Crofts; 1970.

13. Gouda P, Kirk A, Sweeney A-M, O’Donovan D. Attitudes of Medical Students Toward Volunteering in Emergency Situations. Disaster Med Public Health Prep. September 2019:1-4. doi:10.1017/dmp.2019.81

14. Patel VM, Dahl-Grove D. Disaster Preparedness Medical School Elective: Bridging the Gap Between Volunteer Eagerness and Readiness. Pediatr Emerg Care. 2018;34(7):492-496. doi:10.1097/PEC.0000000000000806

15. Rasmussen S, Sperling P, Poulsen MS, Emmersen J, Andersen S. Medical students for health-care staff shortages during the COVID-19 pandemic. Lancet. 2020;395(10234):e79-e80. doi:10.1016/S0140-6736(20)30923-5

16. Astorp MS, Sørensen GVB, Rasmussen S, Emmersen J, Erbs AW, Andersen S. Support for mobilising medical students to join the covid-19 pandemic emergency healthcare workforce: A cross-sectional questionnaire survey. BMJ Open. 2020;10(9). doi:10.1136/bmjopen-2020-039082

17. Yu N-Z, Li Z-J, Chong Y-M, et al. Chinese medical students' interest in COVID-19 pandemic. World J Virol. 2020;9(3):38-46. doi:10.5501/wjv.v9.i3.38

18. Drexler R, Hambrecht JM, Oldhafer KJ. Involvement of Medical Students During the 
medRxiv preprint doi: https://doi.org/10.1101/2021.07.06.21260058; this version posted July 7, 2021. The copyright holder for this preprint (which was not certified by peer review) is the author/funder, who has granted medRxiv a license to display the preprint in perpetuity.

All rights reserved. No reuse allowed without permission.

Coronavirus Disease 2019 Pandemic: A Cross-Sectional Survey Study. Cureus.

19. Pasquier P, Luft A, Gillard J, et al. How do we fight COVID-19? Military medical actions in the war against the COVID-19 pandemic in France. BMJ Mil Heal. August 2020:bmjmilitary-2020-001569. doi:10.1136/bmjmilitary-2020-001569

20. Patel J, Robbins T, Randeva H, et al. Rising to the challenge: Qualitative assessment of medical student perceptions responding to the COVID-19 pandemic. Clin Med

(Northfield Il). October 2020:clinmed.2020-0219. doi:10.7861/clinmed.2020-0219

21. The General Medical Council. The State of Medical Education and Practice in the UK 2020.; 2020.

430 22. The General Medical Council. Medical School Annual Return 2017/2018.; 2018.

431 23. Cresswell J, Plano Clark V. Designing and Conducting Mixed Methods Research. $432 \quad$ Thousand Oaks, California: SAGE; 2007.

433 24. Brown MEL, Dueñas AN. A Medical Science Educator's Guide to Selecting a Research Paradigm: Building a Basis for Better Research. Med Sci Educ. 2020;30(1):545-553. doi:10.1007/s40670-019-00898-9

436 25. Schifferdecker KE, Reed VA. Using mixed methods research in medical education: Basic guidelines for researchers. Med Educ. 2009;43(7):637-644. doi:10.1111/j.13652923.2009.03386.x

439 26. STROBE Initiative. STROBE Checklist for cross-sectional studies.

440 27. Byrne M, Ashcroft J, Alexander L, Wan J, Harvey A. 986 A Systematic Review of Medical Student Willingness to Volunteer and Preparedness for Pandemics and Disasters. Br J Surg. 2021;108(Supplement_2). doi:10.1093/bjs/znab134.185

443 28. Medical Schools Council. Medical schools.

444 29. R Core Team. R: A language and environment for statistical computing. 2017. 
medRxiv preprint doi: https://doi.org/10.1101/2021.07.06.21260058; this version posted July 7, 2021. The copyright holder for this preprint (which was not certified by peer review) is the author/funder, who has granted medRxiv a license to display the preprint in perpetuity.

All rights reserved. No reuse allowed without permission.

445 30. Braun V, Clarke V. Using thematic analysis in psychology. Qual Res Psychol. 2006;3(2):77-101. doi:10.1191/1478088706qp063oa

447 31. Varpio L, Paradis E, Uijtdehaage S, Young M. The Distinctions between Theory, Theoretical Framework, and Conceptual Framework. Acad Med. 2020;95(7):989-994. doi:10.1097/ACM.0000000000003075

32. Bowen GA. Grounded Theory and Sensitizing Concepts. Int J Qual Methods. 2006;5(3):12-23. doi:10.1177/160940690600500304

33. Patel R, Tarrant C, Bonas S, Yates J, Sandars J. The struggling student: a thematic analysis from the self-regulated learning perspective. Med Educ. 2015;49(4):417-426. doi:10.1111/medu. 12651

34. Webb TL, Joseph J, Yardley L, Michie S. Using the Internet to Promote Health Behavior Change: A Systematic Review and Meta-analysis of the Impact of

35. Darley JM, Batson CD. "From Jerusalem to Jericho": A study of situational and dispositional variables in helping behavior. J Pers Soc Psychol. 1973;27(1):100-108. doi:10.1037/h0034449

36. Latané B, Darley JM. Group inhibition of bystander intervention in emergencies. $J$ Pers Soc Psychol. 1968;10(3):215-221. doi:10.1037/h0026570

464 37. Lai FHY, Siu AMH, Shek DTL. Individual and Social Predictors of Prosocial Behavior among Chinese Adolescents in Hong Kong. Front Pediatr. 2015;3. doi:10.3389/fped.2015.00039

467 38. Choukas-Bradley S, Giletta M, Cohen GL, Prinstein MJ. Peer Influence, Peer Status, and Prosocial Behavior: An Experimental Investigation of Peer Socialization of Adolescents' Intentions to Volunteer. J Youth Adolesc. 2015;44(12):2197-2210. 
medRxiv preprint doi: https://doi.org/10.1101/2021.07.06.21260058; this version posted July 7, 2021. The copyright holder for this preprint (which was not certified by peer review) is the author/funder, who has granted medRxiv a license to display the preprint in perpetuity.

doi:10.1007/s10964-015-0373-2

471 39. DiDonato TE, Ullrich J, Krueger JI. Social Perception as Induction and Inference: An 472 Integrative Model of Intergroup Differentiation, Ingroup Favoritism, and Differential Accuracy. J Pers Soc Psychol. 2011;100(1):66-83. doi:10.1037/a0021051

474 40. Krueger JI, Ullrich J, Chen LJ. Expectations and decisions in the Volunteer's dilemma: 475 Effects of social distance and social projection. Front Psychol. 2016;7(DEC). doi:10.3389/fpsyg.2016.01909

477 41. Twenge JM, Ciarocco NJ, Baumeister RF, DeWall CN, Bartels JM. Social exclusion decreases prosocial behavior. J Pers Soc Psychol. 2007;92(1):56-66. doi:10.1037/0022-3514.92.1.56

480 42. Youssef S, Zaidi S, Shrestha S, Varghese C, Rajagopalan S. First impressions of the foundation interim year 1 postings: positives, pitfalls, and perils. Med Educ Online.

43. UK Foundation Programme Office. Impact of COVID-19 on the UK Foundation Programme 2020. 2020.

44. Lee J. How medical students are responding to Covid-19. The Independent.

45. Kinder F, Harvey A. Covid-19: the medical students responding to the pandemic. BMJ. 2020;369:m2160. doi:10.1136/bmj.m2160

46. Thomson E, Lovegrove S. 'Let us Help'-Why senior medical students are the next step in battling the COVID $\square 19$ Pandemic. Int J Clin Pract. 2020;74(8). doi:10.1111/ijcp.13516

47. Wang Z, Jusup M, Shi L, Lee JH, Iwasa Y, Boccaletti S. Exploiting a cognitive bias promotes cooperation in social dilemma experiments. Nat Commun. 2018;9(1). doi:10.1038/s41467-018-05259-5

494 48. Almeida L, Kashdan TB, Coelho R, Albino-Teixeira A, Soares-da-Silva P. Healthy 
medRxiv preprint doi: https://doi.org/10.1101/2021.07.06.21260058; this version posted July 7, 2021. The copyright holder for this preprint (which was not certified by peer review) is the author/funder, who has granted medRxiv a license to display the preprint in perpetuity.

All rights reserved. No reuse allowed without permission.

501

502

503

504

505

506

507

508

509

510

511

512

513

514

515

516

517 57. Center for Disease Control and Prevention. Cases in the US.

518 58. Artino AR, La Rochelle JS, Dezee KJ, Gehlbach H. Developing questionnaires for 519

subjects volunteering for phase I studies: Influence of curiosity, exploratory tendencies and perceived self-efficacy. Int J Clin Pharmacol Ther. 2008;46(3):109-118. doi:10.5414/CPP46109

49. Soled D, Goel S, Barry D, et al. Medical Student Mobilization During A Crisis:

Lessons From A COVID-19 Medical Student Response Team. Acad Med. April 2020. doi:http://dx.doi.org/10.1097/ACM.0000000000003401

50. Medical Schools Council. Student volunteering.

51. Ashcroft J, Byrne MHV, Brennan PA, Davies RJ, Davies RJ. Preparing medical students for a pandemic: A systematic review of student disaster training programmes. Postgrad Med J. 2020;0:1-12. doi:10.1136/postgradmedj-2020-137906

52. Sheather J, Jobanputra K, Schopper D, et al. A Médecins Sans Frontières Ethics Framework for Humanitarian Innovation. PLoS Med. 2016;13(9). doi:10.1371/journal.pmed.1002111

53. Whittaker J, McLennan B, Handmer J. A review of informal volunteerism in emergencies and disasters: Definition, opportunities and challenges. Int J Disaster Risk Reduct. 2015;13:358-368. doi:10.1016/j.ijdrr.2015.07.010

54. Wise J. Covid-19: Risk of second wave is very real, say researchers. BMJ. 2020;369:m2294. doi:10.1136/bmj.m2294

55. Xu S, Li Y. Beware of the second wave of COVID-19. Lancet. 2020;395(10233):1321-1322. doi:10.1016/S0140-6736(20)30845-X

56. Willsher K, Henley J. Covid in Europe: second wave gathers pace across continent. The Guardian. educational research: AMEE Guide No. 87. Med Teach. 2014;36(6):463-474. 
medRxiv preprint doi: https://doi.org/10.1101/2021.07.06.21260058; this version posted July 7, 2021. The copyright holder for this preprint (which was not certified by peer review) is the author/funder, who has granted medRxiv a license to display the preprint in perpetuity.

All rights reserved. No reuse allowed without permission.

521 
medRxiv preprint doi: https://doi.org/10.1101/2021.07.06.21260058; this version posted July 7, 2021. The copyright holder for this preprint

(which was not certified by peer review) is the author/funder, who has granted medRxiv a license to display the preprint in perpetuity.

All rights reserved. No reuse allowed without permission.

\section{AUTHOR DESCRIPTIONS}

523 Matthew H V Byrne is an Academic Clinical Fellow in Urology at Oxford. He has a PGCert

524 in medical education and has previously been awarded a MRes in Transplantation. He

525 founded a national charity that facilitates medical student volunteers delivering talks at

526 secondary schools.

527

528 James Ashcroft is an Academic Clinical Fellow in General Surgery in the East of England

529 Deanery with an interest in early academic education and technical performance training. His

530 educational work has explored cognitive interventions in technical skill (awarded MRes) and

531 early surgical learning (awarded MSc).

532

533 Dr Laith Alexander is currently an Academic Foundation Doctor in Psychological Medicine

534 \& Psychiatry at Guy's and St Thomas' Foundation Trust with King's College London. His

535 interests lie in psychiatry and neuroscience. His $\mathrm{PhD}$ in neuroscience explored the role of the

536 ventromedial prefrontal cortex in the regulation of emotion and cardiovascular function.

538 Dr Jonathan Wan is an Academic Foundation Doctor in Oncology at Guy's and St Thomas'.

539 He carried out his $\mathrm{PhD}$ in computational cancer diagnostics and is continuing his research as

540 a Bioinformatics Engineer at Memorial Sloan Kettering Cancer Center. He is interested in

541 medical and surgical oncology research and medical education.

542

543 Anna Harvey is a final year medical student at King's College London and former Editorial

544 Scholar at The BMJ.

545 
medRxiv preprint doi: https://doi.org/10.1101/2021.07.06.21260058; this version posted July 7, 2021. The copyright holder for this preprint

(which was not certified by peer review) is the author/funder, who has granted medRxiv a license to display the preprint in perpetuity.

All rights reserved. No reuse allowed without permission.

546 Dr Nicholas Schindler is a pediatric registrar at Norfolk and Norwich University Hospitals

547 NHS Foundation Trust, and a Tutor in Medical Education the University of Cambridge

548 Institute of Continuing Education. His research interest is in methods of workplace-based

549 training and assessment in pediatric education (awarded MSt). As Royal College of Pediatrics

550 and Child Health trainee representative for Assessment and Examinations he is involved in

551 the adaptation of assessments and postgraduate examinations for pediatricians during the

552 COVID-19 pandemic.

553

554 Dr Megan Brown is a PhD student in medical education within the Health Professions

555 Education Unit, Hull York Medical School. Her research interests include professional

556 identity development, longitudinal integrated clerkships, empathy and the hidden curriculum.

557

558 Dr Cecilia Brassett is a Fellow at Magdalene College, Cambridge as well as their Joint

559 Director of Studies in Medical Sciences, College Lecturer in Medicine, and Deputy

560 Senior Tutor. She is also the University Clinical Anatomist. She is directly involved in the

561 changes being made to medical student teaching during the COVID-19 pandemic. 
medRxiv preprint doi: https://doi.org/10.1101/2021.07.06.21260058; this version posted July 7, 2021. The copyright holder for this preprint (which was not certified by peer review) is the author/funder, who has granted medRxiv a license to display the preprint in perpetuity.

All rights reserved. No reuse allowed without permission.

\section{FIGURES}

563 Figure 1: Willingness to perform roles during the pandemic, both (a) on a general

564 ward, and (b) on a coronavirus ward. (c) Confidence in clinical skills by year. Mean values

565 and $95 \%$ confidence intervals are shown. The mean confidence score across all students is

566 shown with a dashed line.

567 Figure 2: Conceptual framework for medical student prosocial behaviour during COVID-19. 
medRxiv preprint doi: https://doi.org/10.1101/2021.07.06.21260058; this version posted July 7, 2021. The copyright holder for this preprint (which was not certified by peer review) is the author/funder, who has granted medRxiv a license to display the preprint in perpetuity.

All rights reserved. No reuse allowed without permission.

\section{SUPPLEMENTARY FIGURES}

569 Figure S 1: Respondent demographics. (a) Number of medical students from each medical

570 school, divided by gender. (b) Total number of students, by gender. (c) Distribution of year

571 groups of medical students divided by gender. (d) Pie chart indicating if students had already

572 started as volunteers during the pandemic. (e) Proportion of students volunteering by year.

573 The proportion of non-intercalating students volunteering at the time of the survey ranged

574 from $14.6 \%$ among first-year students to $62.8 \%$ in sixth-year students

575 Figure S 2: Opinions on volunteering on a Likert scale.

$576 \quad$ Figure S 3: Roles students are willing to perform while volunteering grouped by year. 
medRxiv preprint doi: https://doi.org/10.1101/2021.07.06.21260058; this version posted July 7, 2021. The copyright holder for this preprint (which was not certified by peer review) is the author/funder, who has granted medRxiv a license to display the preprint in perpetuity.

All rights reserved. No reuse allowed without permission.

Table 1: Motivating and barrier factors for volunteering

\begin{tabular}{|l|l|l|}
\hline Motivating factors & $\mathbf{n}=$ & $\mathbf{\%}$ \\
\hline Altruism (e.g. Helping those in need) & 1030 & 90.7 \\
\hline $\begin{array}{l}\text { Professional development and training (e.g. Opportunity to learn new } \\
\text { skills and gain experience) }\end{array}$ & 906 & 79.8 \\
\hline Moral obligation (e.g. Need to do the 'right' thing) & 880 & 77.5 \\
\hline Pay & 641 & 56.5 \\
\hline Career (e.g. Opportunity to improve cv make new contacts) & 631 & 55.6 \\
\hline Guilt you would feel if not volunteering & 525 & 46.3 \\
\hline Societal expectations & 250 & 22.0 \\
\hline Medical school expectation or directive & 194 & 17.1 \\
\hline Peer pressure & 142 & 12.5 \\
\hline Other: Activity during lockdown & 26 & 2.3 \\
\hline Barrier factors & 26 & 2.3 \\
\hline Family/social commitments (e.g. Caring for a family member) & $\mathbf{n =}$ & $\mathbf{\%}$ \\
\hline Academic commitments & 690 & 63.2 \\
\hline Lack of personal protective equipment for healthcare staff & 618 & 56.6 \\
\hline Lack of information on volunteering opportunities available & 576 & 52.7 \\
\hline Personal safety (fear of catching coronavirus) & 475 & 43.5 \\
\hline Pre-existing health conditions & 424 & 38.8 \\
\hline Financial implications & 318 & 29.1 \\
\hline Psychological impact & 240 & 22.0 \\
\hline Work commitments & 203 & 18.6 \\
\hline $\begin{array}{l}\text { Other: Transmission to others; Transport; Unable to secure } \\
\text { volunteering opportunity; Competence; Volunteer role; Support }\end{array}$ & 182 & 16.7 \\
\hline
\end{tabular}

2 
1 Table 2: Concerns about volunteering during a pandemic from medical students. 798 out of 1145 students (69.7\%) described issues they

2 believed they would face when volunteering, and 25 students stated they predicted no issues. 365 out of 1145 students (31.9\%) described ethical

3 concerns associated with volunteering, and three students stated there were no ethical concerns. From these responses we identified five themes:

4 safety, professional practice, pressure to volunteer, finances and logistics, and education.

\begin{tabular}{|c|c|c|c|}
\hline Theme & Group & Subgroup & Example \\
\hline \multirow{11}{*}{$\frac{\vec{e}}{\stackrel{e}{\hbar}}$} & \multirow[t]{4}{*}{ Personal safety } & Personal risk of coronavirus & $\begin{array}{l}\text { "Medical students could be put in harms way if volunteering around COVID+ } \\
\text { patients" }\end{array}$ \\
\hline & & Health issues & $\begin{array}{l}\text { "Some medical students will have underlying medical conditions that may put them at } \\
\text { risk of contracting or having more serious consequences from COVID-19" }\end{array}$ \\
\hline & & PPE & "Lack of PPE leading to medical students being exposed to danger" \\
\hline & & Psychological impact & $\begin{array}{l}\text { "Medical students, especially younger years may not have had much clinical } \\
\text { experience yet and may experience quite upsetting scenes" }\end{array}$ \\
\hline & \multirow[t]{3}{*}{ Other's safety } & Vulnerable family & "Transmitting to vulnerable family members I live with" \\
\hline & & Viral transmission to others & $\begin{array}{l}\text { "The greater number of medical students that work, the more the virus spreads } \\
\text { through them to their homes" }\end{array}$ \\
\hline & & Caring responsibilities & $\begin{array}{l}\text { "Extra experience for those able to do unpaid work, while those who are carers ... are } \\
\text { not able" }\end{array}$ \\
\hline & \multirow[t]{2}{*}{ Safe practice } & Patient safety & "Is patient safety being put at risk by graduating doctors that haven't sat finals" \\
\hline & & Working outside of competence & "Inability to say no to tasks I am not confident in" \\
\hline & \multirow[t]{2}{*}{ Support } & Supervision & "Not having sufficient support due to overworked supervisory staff." \\
\hline & & Staffing issues & "Low staff numbers" \\
\hline \multirow{7}{*}{ 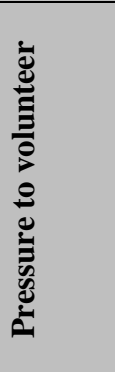 } & \multirow[t]{7}{*}{ Pressure to volunteer } & General pressure & "Students should not feel pressured when being asked." \\
\hline & & Coercion & $\begin{array}{l}\text { "I would only be concerned if people felt that they had no choice but to volunteer to } \\
\text { work" }\end{array}$ \\
\hline & & Obliged & $\begin{array}{l}\text { "I don't think asking medical students to volunteer is a problem, but it may cause } \\
\text { some students to feel obliged to volunteer" }\end{array}$ \\
\hline & & Promotion & "I think the option should be offered, but in a very neutral manner" \\
\hline & & Own choice & "If students come forward, asking if they can help, that's their decision" \\
\hline & & Guilt & "It is easy to feel guilty about not working in hospital" \\
\hline & & External pressure & "Universities pressuring students to volunteer"; "Peer pressure" \\
\hline
\end{tabular}




\begin{tabular}{|c|c|c|c|}
\hline \multirow{12}{*}{ 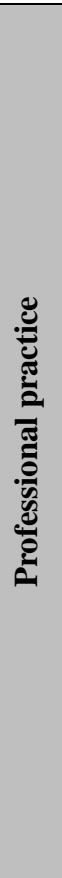 } & \multirow[t]{3}{*}{ Competence } & Inexperience & "Students may have insufficient experience" \\
\hline & & Burden & $\begin{array}{l}\text { "Some students may be beneficial to the NHS while others may need too much } \\
\text { support and supervision etc and therefore be a hindrance at this time." }\end{array}$ \\
\hline & & Usefulness & $\begin{array}{l}\text { "I am currently a junior medical student so I worry I would not be as useful as } \\
\text { students who are more senior" }\end{array}$ \\
\hline & \multirow[t]{2}{*}{ Professional role boundaries } & Unclear role for staff and student & "Blurred lines of responsibility and expectations for medical students" \\
\hline & & Ask outside of competence & "Concerned we will be asked to work beyond our capacity." \\
\hline & \multirow[t]{3}{*}{ Discrimination } & $\begin{array}{l}\text { Discrimination by not } \\
\text { volunteering }\end{array}$ & "Discrimination against Medical Students that did not volunteer." \\
\hline & & Career prospects & $\begin{array}{l}\text { "Pressure on students who think they need to work in case it negatively affects their } \\
\text { career if they don't."; "expectations for future career interviews if someone did/did } \\
\text { not volunteer and that being used against your application"; "need to ensure that there } \\
\text { were no penalties for these students who did not volunteer". }\end{array}$ \\
\hline & & Ethnicity & $\begin{array}{l}\text { "with the recent issue of BAME healthcare workers being disproportionately affected } \\
\text { from Covid-19 ... I worry that medical students volunteering may be } \\
\text { disproportionately affected as well."; "Patients may be racist, refusing help from } \\
\text { Chinese medical students" }\end{array}$ \\
\hline & \multirow[t]{2}{*}{ Legal } & Indemnity & $\begin{array}{l}\text { "Lack of a protective union for students in particular"; "Insurance coverage should } \\
\text { we make a mistake" }\end{array}$ \\
\hline & & Contract & "Starting work without a contract" \\
\hline & \multirow[t]{2}{*}{ Work } & Concerns about work & "Job will be boring/'unglamorous"” \\
\hline & & Hospital issues & "Working in stretched system" \\
\hline \multirow{6}{*}{ 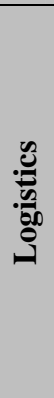 } & \multirow[t]{3}{*}{ Logistics } & Accommodation & "Will need new accommodation, won't be able to stay at home" \\
\hline & & Transport & $\begin{array}{l}\text { "I don't have a car and would be unsure whether public transport would be } \\
\text { appropriate - I live far out from major hospitals." }\end{array}$ \\
\hline & & Administrative & "Admin issues" \\
\hline & Support & Support outside of work & $\begin{array}{l}\text { "Not being able to see my friends and family outside of my house will be difficult"; } \\
\text { "Lack of peer and colleague support"; "Lack of university support" }\end{array}$ \\
\hline & \multirow[t]{2}{*}{ Financial } & Lack of pay & $\begin{array}{l}\text { "I think if students are asked to join the workforce during a pandemic then they must } \\
\text { be paid something." }\end{array}$ \\
\hline & & Financial difficulties & $\begin{array}{l}\text { "Students are considered financially vulnerable for clinical trial purposes, similar } \\
\text { ethical concerns exist around paid volunteer opportunities" }\end{array}$ \\
\hline \multirow{2}{*}{ 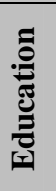 } & \multirow[t]{2}{*}{ University education } & Educational disruption & $\begin{array}{l}\text { "If we choose not to volunteer, we risk being under skilled compared to our } \\
\text { contemporaries who do volunteer"; "Even further loss of study time" }\end{array}$ \\
\hline & & Work-educational balance & $\begin{array}{l}\text { "Volunteering can take students away from their focus on the degree"; "we have } \\
\text { exams imminently and have been told if we choose to volunteer we are expected to } \\
\text { still perform in exams, and the exams will still contribute towards deciles ... Many of }\end{array}$ \\
\hline
\end{tabular}


us have had to choose between doing what we can to help and risking our education"

Professional education

Lack of training

Learning how to work
"Inappropriate clinical training"; "Without proper training/preparation, harm may also be done to patients or healthcare staff supervising students"

"The 'learning' time it takes to learn how the job works" 
medRxiv preprint doi: https://doi.org/10.1101/2021.07.06.21260058; this version posted July 7, 2021. The copyright holder for this preprint (which was not certified by peer review) is the author/funder, who has granted medRxiv a license to display the preprint in perpetuity. All rights reserved. No reuse allowed without permission.

1 Table 3: Suggestions to facilitate medical student prosocial behaviour during pandemics and

\section{2 disasters}

Recognising there is an emergency situation

- Transparency around communications with medical students

\section{Deciding responsibility}

- Transparency around communications with medical students

○ Non-biased advertising of roles

- No mandated recruitment - if required (for example in a catastrophic disaster), this must be a last resort and should not expose vulnerable parties

- $\quad$ Planning should involve medical students and medical educators, and it should have clear triggers for activating medical students into the workforce.

- Distinction between service provision and training should be clear - again there should be clear triggers

○ Remuneration for service provision positions

- $\quad$ Minimise disruption to education where possible

○ Aim to align volunteering opportunities to learning outcomes where possible

- Hospitals to work with universities to allow education to continue where possible and to minimise conflict with work shifts

- Consider postponing or cancelling examinations depending on level of disruption

- Do not disadvantage those who did not volunteer in future interview processes

○ Provide alternative learning arrangements for those who cannot volunteer

\section{Deciding skills and knowledge}

- Clear roles for medical students

○ Personalised holistic volunteering roles:

- These could be tailored to medical school year or competencies

- Consider the roles that students who cannot volunteer in clinical settings can do (e.g. vulnerable individuals or family members) - such as contact tracing

- The limits of each role should be communicated to other staff members within the hospital

- Aim to reduce exposure to patients affected by the pandemic/disaster for junior students where possible

- Avoid assigning students to on-call shifts where possible.

○ Ensure all volunteers have a contract and indemnity cover prior to starting

- $\quad$ Provide additional training

- Specific disaster/pandemic training following our previous suggestions (Ashcroft et al. ${ }^{57}$ )

- Tailored induction program for volunteers who have had minimal hospital exposure previously

\section{Deciding safety}

- Ensure patient safety

○ Named educational supervisor for every medical student

○ Explicitly educate students on safety pathways such as exception reporting and clinical incident reporting

- $\quad$ Ensure volunteer safety

- Adequate PPE and PPE training for volunteers

- $\quad$ Provide wellbeing services

- Pastoral support for both those who are can and cannot volunteer

- Sign posting to financial support

- Support for students with caring responsibilities or health issues of their own

○ Ensure adequate physical and mental health support services

\section{Deciding Logistics}

- Transparency around communications with medical students

$\circ$ Clear process of how to sign up as a volunteer and obtaining work

○ Clear description of transport and accommodation amenities 
medRxiv preprint doi: https://doi.org/10.1101/2021.07.06.21260058; this version posted July 7, 2021. The copyright holder for this preprint (which was not certified by peer review) is the author/funder, who has granted medRxiv a license to display the preprint in perpetuity.

All rights reserved. No reuse allowed without permission. 
It I volunteer, I would be willing to carry outperform..

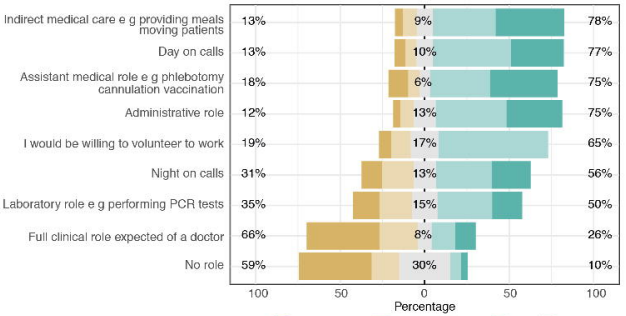

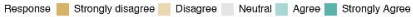

It I volunteer, I would be willing to carry outpertorm the following on a COVID-19 ward...
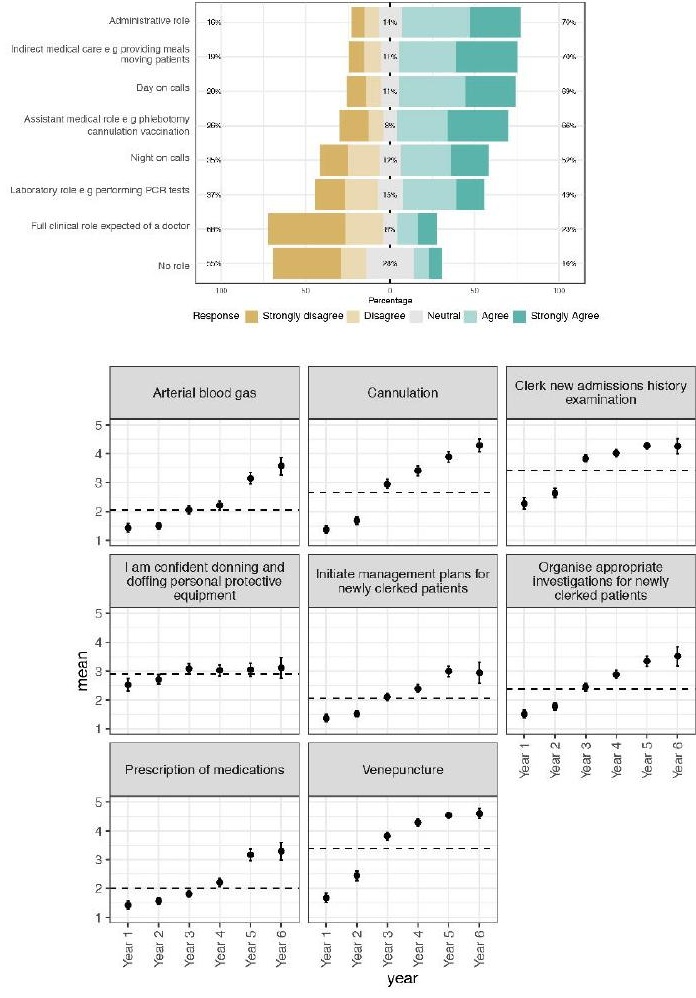

Organise appropriate investigations for newly clerked patients

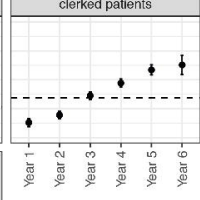


